\title{
Physical activity and self treatment in cystic fibrosis
}

\author{
M BILOMQUIST, U FREYSCHUSS, L-G WIMAN, AND B STRANDVIK
}

Departments of Physiotherapy, Clinical Physiology, Lung Medicine, and Paediatrics, Karolinska Institute, Huddinge University Hospital, Stockholm, Sweden

SUMMARY A programme of increased physical activity and self treatment based on the forced expiration technique was introduced to 14 adolescent patients with cystic fibrosis, diagnosed since infancy or early childhood, who had gastrointestinal and pulmonary symptoms. Twelve patients who fulfilled the one year programme had unchanged clinical conditions, pulmonary function tests, and chest $x$ ray films. There was a significant improvement in oxygen pressure correlated to the period of increased physical activity. Other blood gas variables, including $\mathrm{pH}$, standard bicarbonate, and base excess, also indicated significant changes, mainly during exercise. The study shows that daily physical activity improves the pulmonary gas exchange and that self treatment combined with physical activity is as efficient as conventional physiotherapy.

In cystic fibrosis the most serious symptoms come from the viscous secretions that cause plugging and bacterial colonisation of the small airways, leading to recurrent infections and pneumoniae. Previously, this disease meant death in early childhood, but with improved methods of treatment most children with this disease reach adulthood. Chest physiotherapy combined with appropriate antibiotics are the most important components in controlling pulmonary complications and maintaining a good pulmonary function. ${ }^{1}$ The time consuming chest physiotherapy -often 2-3 times a day-implies dependence on institutions or on other people, be they physiotherapists or parents. This great dependence causes special social problems during childhood and adolescence. Difficulties may occur both for the patients and their relatives in the choice of residence, place of study, holidays, and different activities. The general purpose of modern treatment is to enable these patients to be more independent of other people and thereby acquire a better quality of life.

The aim of the present study was to evaluate if a method of self treatment ${ }^{2}$ was comparable in efficiency with conventional treatment with chest physiotherapy. As a part of the self treatment programme physical activity was increased, making a two step design of the study.

\section{Patients}

Fourteen patients, eight girls and six boys, aged
13-23 (mean $17 \cdot 8$ years), agreed to participate in the study after fulfilling the following criteria:

(1) they had the motivation to cooperate in the whole study;

(2) they were living within a reasonable distance from the hospital;

(3) they had the interest and possibility, judged upon medical criteria, to take part in some sort of physical activity;

(4) they were old enough to understand the intention of the study and to have a desire to be independent of other people for their own treatment.

All the patients had normal height and weight. Mean height of the girls was $165.7 \mathrm{~cm}$ (range 158-170) and of the boys was $170.2 \mathrm{~cm}$ (range $153-190$ ), mean weight being $62.2 \mathrm{~kg}$ (range $52-73$ ) and $55.8 \mathrm{~kg}$ (range $38-69$ ), respectively. All patients had pathological sweat tests (chloride $>80 \mathrm{mmol} / \mathrm{l}$ ) and pulmonary and gastrointestinal symptoms. Results of pulmonary function tests showed moderate to mild disease in most patients: forced expiratory vital capacity at rest averaged $77.3 \%$ of predicted values (range 58.2-110.5), forced expiratory volume at one second $\left(\mathrm{FEV}_{1}\right) 63.4 \%$ (range 44.2-112.9), forced expiratory volume/forced vital capacity ratio (FEV\%) $69.5 \%$ (range $55 \cdot 0-83 \cdot 0$ ) and maximal expiratory flow at $50 \%$ vital capacity $\left(\mathrm{MEF}_{50}\right)$ 53.1\% (range 18.6-127.2). Arterialised capillary blood gases showed slightly abnormal values; oxygen pressure at rest averaged $8.0 \mathrm{kPa}$ 
(range 7.0-9.0), carbon dioxide pressure $5 \cdot 1 \mathrm{kPa}$

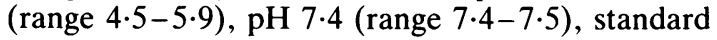
bicarbonate $24.4 \mathrm{mmol} / \mathrm{l}(\mathrm{mEq} / \mathrm{l})$ (range $20 \cdot 0-27 \cdot 0)$, and base excess $-0.2 \mathrm{mmol} / \mathrm{l}(\mathrm{mEq} / \mathrm{l})$ (range $-6-+3$ ). All except three were chronically colonised with Pseudomonas aeruginosa; six had Staphylococcus aureus as well. Three patients had only Staphylococcus aureus in their sputum. All had been diagnosed in childhood and had been seen at monthly check ups and treated for years in the conventional manner, including pancreatic enzyme supplementation, fat soluble vitamins, oral mucolytics, and inhalation therapy. These treatments were unchanged during the study. All patients had had conventional physiotherapy, including postural drainage, percussion, and compression prescribed once or twice a day for years. Six patients had regularly taken part in the organised school sports, while six, who worked full time, exercised more occasionally. The study was approved by the ethical committee of the Karolinska Institute.

\section{Experimental design and methods}

The study was divided into two parts, each planned for a period of six months.

Phase A. This included treatment with conventional chest physiotherapy-postural drainage, percussion, and compression-performed by the patient's physiotherapist or parent, or both, in combination with increased physical activity adjusted to personal interest and capacity, such as jogging, horse riding, dancing, gymnastics, judo, bowling, motor cross, and racket sports. In addition, all the participants were asked to skip rope immediately before the chest physiotherapy treatment. The physical activity was prescribed twice a day for a minimum of 15 minutes each time and until the pulse reached at least $75 \%$ of that obtained during maximum working capacity. The patient was instructed to count the pulse rate after the training sessions.

Phase B. In this phase the patients were adjusted to self treatment with the physical activity continuing as in phase A. The self treatment included a slightly modified 'huffing' technique or forced expiration technique $^{2}$ as well as self percussion, self compression, and postural drainage.

To produce a huff, the patients were instructed to take a small breath and then with open mouth forcefully squeeze air out of the lungs. The abdominal muscles contracted firmly during the huff. The huff had to be long enough to move secretions upwards. If a patient found huffing difficult, he learned to huff by blowing through a tube. ${ }^{3}$ The forced expiration technique meant that the patient in all positions started with relaxed controlled breathing, followed by three or four deep breaths combined with chest percussion, and continued thereafter with a pause for relaxed controlled breathing, followed by one or two effective huffs combined with chest compression, and finishing with quiet breathing. When the secretions reached the upper airways a deep breath was followed by a huff or cough to clear the secretions. This cycle was repeated continuously until the relevant area of the lung had been drained as clear as possible.

The patients received forms to register the daily physical activity during phases $A$ and $B$. The forms were exchanged at the monthly clinical check ups, which included determination of clinical score according to Shwachmann ${ }^{4}$ and height and weight measurements. Chest radiology, pulmonary function tests, ${ }^{5}$ and working capacity, including arterialised capillary blood gas analyses, were examined before the start of the study and after phases A and B. Results from spirometric investigations were related to normal values for age. ${ }^{6-8}$ Blood gas analyses were performed with conventional electrode technics (ABL 2, Radiometer, Copenhagen). Regional lung function tested with ${ }^{133}$ Xenon was evaluated by a score system (see below) based on deviations from the normal value (to be published). A figure of 0 was given for values within normal range; 1 for values within an interval of the same size on both sides of the normal range, and 2 for values within the next outer multiple of the range:

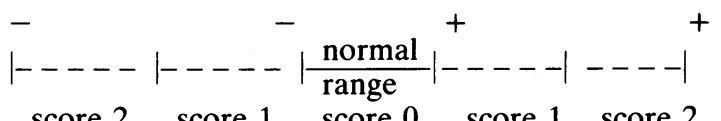

$\begin{array}{lllll}\text { score } 2 & \text { score } 1 & \text { score } 0 & \text { score } 1 & \text { score } 2\end{array}$

The score was based on the following variables: (1) time of elimination of injected isotope and (2) of inhaled isotope, (3) regional ventilation, (4) regional perfusion, and (5) ventilation:perfusion ratios.

After finishing the study the patients and the parents received a questionnaire about their subjective experiences of the changed treatment routine.

Statistical analysis was made by using Student's approximative paired $t$ test.

\section{Results}

Twelve of the 14 participants completed the study. Two patients (both girls) could not hold to the strict programme for such a long time. Phase A lasted for a mean of six months (range five-11) and phase B for nine months (range five-16). The phases were 
prolonged in some cases due to admission to hospital, university studies, and travels, which made the participants unwilling to perform the investigations necessary to change the programme phases. The physical activity, which was planned to be constant during the two phases, increased during phase $\mathrm{B}$ subjectively in three patients and objectively in five. Mean value of the increase was 1.4 hours/week (range $0 \cdot 6-2 \cdot 3$ ). Two patients decreased their activity during phase B. Only one patient did not carry out any kind of physical activity for more than 15 minutes daily. No participant completed the rope skipping. Eight patients experienced the self treatment method with physical activity as positive, while four were undecided. Six felt physically and mentally stronger with the changed treatment routine. After the study was finished none wanted to return to the previous type of treatment.

The questionnaires from the parents showed that seven had not treated their child at all during phase $B$, while five had continued the treatment but to a much lesser extent; one patient was treated regularly once a week for 30 minutes, one once or twice a day for 40 minutes, and three received treatment only occasionally (less than once a week). The reason why some patients continued to receive conventional physiotherapy was mainly psychological. They wanted the care and nearness of another person.

Nevertheless, nine parents expressed the opinion that the children could take responsibility for their own treatment. The economical benefit for the individual and for the society was impressive without the treatment being more time consuming for the patients. The mean value of treatment help during phase $A$ was 2.6 hours/week (range 1.0-5.0) and during phase $\mathrm{B}$ was 0.5 hour/week (range $0-3 \cdot 0$ ). During phase $B$ the mean value of self treatment was $2 \cdot 3$ hours/week (range $0 \cdot 25-7 \cdot 0$ ). Some patients did not follow the prescriptions of physiotherapy before the study started, but these patients continued with less physiotherapy during the whole study, only changing the part requiring help by others.

All patients had normal height and weight for age and grew normally during the study. The mean clinical score according to Shwachmann was 82.0 (range 62-91) at the start and did not change significantly. The prevalence of infections was the same as that during the two preceding years. The $x$ ray findings and the results of the lung function tests did not show any significant changes during the study. There was a tendency towards improvement of the forced expiratory vital capacity and forced expiratory volume at one second (Table 1 ). The regional lung function (Table 2) and working capacity showed no significant changes. The mean work load for girls at a heart rate of 170 beats/ minute was $136 \cdot 2 \mathrm{~W}$ (range $97-150$ ) or $2.2 \mathrm{~W}$ per kilo body weight (range $1 \cdot 7-2 \cdot 5$ ) at the start of the

Table 1 Changes of lung function variables in percentage of normal values (a) before work and (b) five minutes after work. Values are mean (SD)

\begin{tabular}{|c|c|c|c|c|}
\hline & & $\begin{array}{l}\text { From start to } \\
\text { end of phase } A\end{array}$ & $\begin{array}{l}\text { From start to } \\
\text { end of phase } B\end{array}$ & $\begin{array}{l}\text { From start of phase } \\
A \text { to end of phase } B\end{array}$ \\
\hline Forced expiratory vital capacity* & $\begin{array}{l}\text { (a) } \\
\text { (b) }\end{array}$ & $\begin{array}{l}6 \cdot 6(14 \cdot 4) \\
5 \cdot 2(11 \cdot 5)\end{array}$ & $\begin{array}{ll}-1 \cdot 4 & (7 \cdot 1) \\
-1 \cdot 8 & (6 \cdot 6)\end{array}$ & $\begin{array}{l}5 \cdot 2(14 \cdot 6) \\
3.4(11.9)\end{array}$ \\
\hline Forced expiratory volume at one second ${ }^{*}$ & $\begin{array}{l}\text { (a) } \\
\text { (b) }\end{array}$ & $\begin{array}{rr}5 \cdot 0 & (14 \cdot 4) \\
3 \cdot 4 & (6 \cdot 8)\end{array}$ & $\begin{array}{l}-0.3(10 \cdot 0) \\
-0.5(10 \cdot 7)\end{array}$ & $\begin{array}{l}4 \cdot 7(14 \cdot 0) \\
2 \cdot 9(11 \cdot 1)\end{array}$ \\
\hline $\begin{array}{l}\text { Forced expiratory volume/forced } \\
\text { vital capacity }\end{array}$ & $\begin{array}{l}\text { (a) } \\
\text { (b) }\end{array}$ & $\begin{array}{l}-0 \cdot 5(10 \cdot 1) \\
-0 \cdot 1 \quad(6 \cdot 1)\end{array}$ & $\begin{array}{ll}1 \cdot 0 & (6 \cdot 5) \\
0 \cdot 8 & (7 \cdot 6)\end{array}$ & $\begin{array}{ll}0 \cdot 5 & (4 \cdot 8) \\
0 \cdot 7 & (6 \cdot 5)\end{array}$ \\
\hline $\begin{array}{l}\text { Maximal expiratory flow at } 50 \% \\
\text { vital capacity* }\end{array}$ & $\begin{array}{l}\text { (a) } \\
\text { (b) }\end{array}$ & $\begin{array}{l}5 \cdot 7(19 \cdot 5) \\
2 \cdot 8(11 \cdot 0)\end{array}$ & $\begin{array}{r}2.4(13.4) \\
-0 \cdot 2(19.5)\end{array}$ & $\begin{array}{ll}8 \cdot 1(20 \cdot 9) \\
2 \cdot 6(16 \cdot 1)\end{array}$ \\
\hline
\end{tabular}

"Body temperature pressure saturation.

Table 2 Changes in regional lung function score. Values are mean (SD)

\begin{tabular}{|c|c|c|c|}
\hline & $\begin{array}{l}\text { From start to } \\
\text { end of phase } A\end{array}$ & $\begin{array}{l}\text { From start to } \\
\text { end of phase } B\end{array}$ & $\begin{array}{l}\text { From start of phase } \\
A \text { to end of phase } B\end{array}$ \\
\hline $\begin{array}{l}\text { Right apex } \\
\text { Left apex } \\
\text { Right base } \\
\text { Left base }\end{array}$ & $\begin{array}{r}0.7(2.1) \\
-0.8(2.6) \\
-1.3(2.3) \\
-0.9(2.2)\end{array}$ & $\begin{array}{r}-0.3(2.3) \\
0.3(2.2) \\
0.8(1.7) \\
0.3(1.7)\end{array}$ & $\begin{array}{r}0.3(1.6) \\
-0.5(2.0) \\
-0.4(3.1) \\
-0.7(3.0)\end{array}$ \\
\hline Total & $-2.3(6 \cdot 5)$ & $1 \cdot 0(6 \cdot 1)$ & $-1.3(7 \cdot 0)$ \\
\hline
\end{tabular}


Table 3 Absolute changes in blood gas data (a) at rest and (b) during maximal work. Values are mean (SD)

\begin{tabular}{|c|c|c|c|c|}
\hline & & $\begin{array}{l}\text { From start to } \\
\text { end of phase } A\end{array}$ & $\begin{array}{l}\text { From start to } \\
\text { end of phase } B\end{array}$ & $\begin{array}{l}\text { From start of phase } \\
A \text { to end of phase } B\end{array}$ \\
\hline Oxygen pressure (kPa) & $\begin{array}{l}\text { (a) } \\
\text { (b) }\end{array}$ & 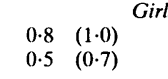 & $\begin{array}{rr}-0.7 & (1.4) \\
1.3 & (1.7)\end{array}$ & $\begin{array}{ll}0.1 & (0.8) \\
1.6 & (1.4)\end{array}$ \\
\hline Carbon dioxide pressure $(\mathrm{kPa})$ & $\begin{array}{l}\text { (a) } \\
\text { (b) }\end{array}$ & $\begin{array}{ll}0 \cdot 2 & (0 \cdot 4) \\
0 \cdot 3 & (0 \cdot 3)\end{array}$ & $\begin{array}{ll}-0.3 & (0.5) \\
-0.3 & (0 \cdot 6)\end{array}$ & $\begin{array}{ll}-0.0 & (0.4) \\
-0.1 & (0.4)\end{array}$ \\
\hline pH at work (units) & $\begin{array}{l}\text { (a) } \\
\text { (b) }\end{array}$ & $\begin{array}{r}0.00(0.05) \\
-0.01(0.04)\end{array}$ & $\begin{array}{r}0.01(0.04) \\
-0.02(0.03)^{*}\end{array}$ & $\begin{array}{r}0.01(0.02) \\
-0.03(0.04)^{*}\end{array}$ \\
\hline Standard biocarbonate $(\mathrm{mmol} / \mathrm{l})$ & $\begin{array}{l}\text { (a) } \\
\text { (b) }\end{array}$ & $\begin{array}{ll}0.8 & (3.1) \\
0.3 & (1.4)\end{array}$ & $\begin{array}{ll}-0.3 & (2 \cdot 8) \\
-1 \cdot 8 & (2 \cdot 3)^{*}\end{array}$ & $\begin{aligned} 0.5 & (1.4) \\
-1.4 & (2 \cdot 1)^{*}\end{aligned}$ \\
\hline Base excess (mmol/l) & $\begin{array}{l}\text { (a) } \\
\text { (b) }\end{array}$ & $\begin{array}{ll}0.8 & (3.4) \\
0.7 & (1.8)\end{array}$ & $\begin{array}{rr}0.6 & (3.3) \\
-1.8 & (3.0)\end{array}$ & $\begin{array}{rr}1.0 & (1.9) \\
-0.8 & (1.7)\end{array}$ \\
\hline Oxygen pressure (kPa) & $\begin{array}{l}\text { (a) } \\
\text { (b) }\end{array}$ & 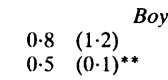 & $\begin{array}{rr}0.2 & (1.8) \\
-0.1 & (0.9)\end{array}$ & $\begin{array}{ll}1 \cdot 1 & (0 \cdot 8)^{*} \\
0.5 & (0 \cdot 9)^{2}\end{array}$ \\
\hline Carbon dioxide pressure $(\mathrm{kPa})$ & $\begin{array}{l}\text { (a) } \\
\text { (b) }\end{array}$ & $\begin{array}{ll}0 \cdot 2 & (0 \cdot 4) \\
0 \cdot 1 & (0 \cdot 3)\end{array}$ & $\begin{array}{ll}-0 \cdot 3 & (0 \cdot 4) \\
-0.6 & (0 \cdot 7)\end{array}$ & $\begin{array}{ll}-0 \cdot 1 & (0.4) \\
-0.6 & (0.6)\end{array}$ \\
\hline $\mathrm{pH}$ at work (units) & $\begin{array}{l}\text { (a) } \\
\text { (b) }\end{array}$ & $\begin{array}{r}-0.01(0.03) \\
0.01(0.02)\end{array}$ & $\begin{array}{l}-0.02(0.03) \\
-0.01(0.04)\end{array}$ & $\begin{array}{l}-0.02(0 \cdot 04) \\
-0.02(0 \cdot 02)^{* *}\end{array}$ \\
\hline Standard biocarbonate $(\mathrm{mmol} / \mathrm{l})$ & $\begin{array}{l}\text { (a) } \\
\text { (b) }\end{array}$ & $\begin{array}{ll}-0 \cdot 2 & (1 \cdot 5) \\
-0.2 & (1 \cdot 1)\end{array}$ & $\begin{array}{ll}-2 \cdot 0 & (1 \cdot 4)^{* *} \\
-1 \cdot 8 & (3 \cdot 0)\end{array}$ & $\begin{array}{ll}-2 \cdot 0 & (2 \cdot 2)^{* *} \\
-2 \cdot 0 & (2 \cdot 1)^{* *}\end{array}$ \\
\hline Base excess $(\mathrm{mmol} / \mathrm{l})$ & $\begin{array}{l}\text { (a) } \\
\text { (b) }\end{array}$ & $\begin{aligned} 0 \cdot 2 & (2 \cdot 1) \\
-0.2 & (1 \cdot 6)\end{aligned}$ & $\begin{aligned} 2 \cdot 2 & (5 \cdot 3) \\
-2.5 & (3.9)^{*}\end{aligned}$ & $\begin{aligned} 1 \cdot 8 & (5 \cdot 0) \\
-2 \cdot 8 & (3 \cdot 1)^{* *}\end{aligned}$ \\
\hline
\end{tabular}

${ }^{*} \mathrm{p}<0 \cdot 05 ;{ }^{* *} \mathrm{p}<0 \cdot 01$.

Conversion: SI to traditional units-Bicarbonate: $1 \mathrm{mmol} / \mathrm{l}=1 \mathrm{mEq} / \mathrm{l}$; Base excess: $1 \mathrm{mmol} / \mathrm{l}=1 \mathrm{mEq} / \mathrm{l}$.
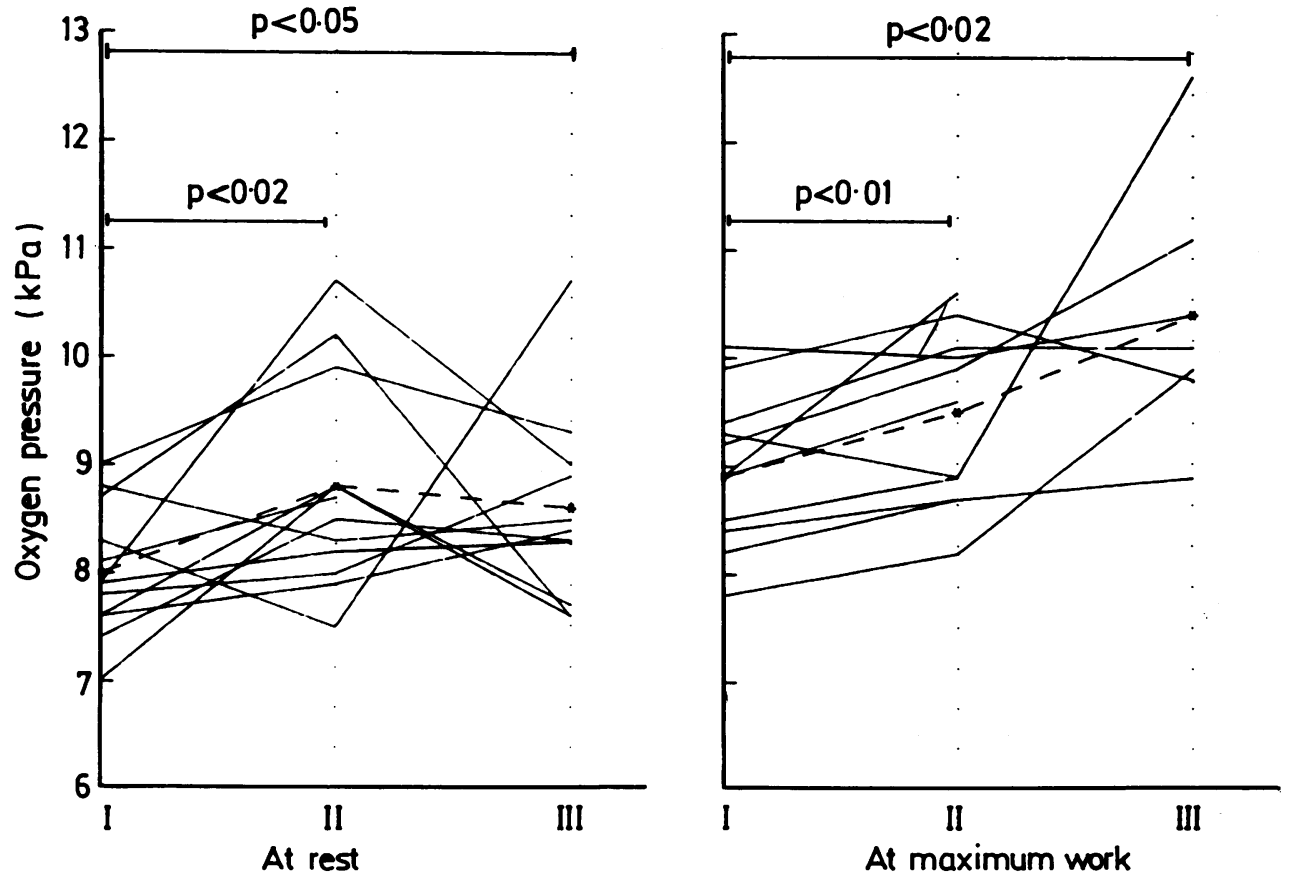

Figure Absolute changes in arterialised capillary oxygen pressure $(k P a)$ in 11 patients with cystic fibrosis (six girls and five boys), (a) at rest and (b) during maximal work. (- - - mean values.) Investigations shown are before phase $A(I)$, after phase $A$ and before phase $B(I I)$, and after phase $B(I I I)$. 
study and $142.0 \mathrm{~W}$ (range $110-172$ ) or $2.3 \mathrm{~W}$ per kilo body weight (range $2 \cdot 0-2 \cdot 6$ ) at the end. The corresponding values for the boys were $146.0 \mathrm{~W}$ (range 100-191) and 2.6 W per kilo body weight (range 1.9-3.5) and $142.8 \mathrm{~W}$ (range 109-200) or 2.4 W per kilo body weight (range $1 \cdot 8-3 \cdot 2$ ), respectively. Arterialised capillary blood gas analyses showed small changes between girls and boys (Table 3 ). There was a significant improvement in oxygen pressure at rest and at maximum work after phase A as well as throughout the whole study for the entire group ( $<<0.05$ and $\mathrm{p}<0.02$, respectively) (Figure). There was a corresponding but not significant decrease in carbon dioxide pressure. Standard bicarbonate, $\mathrm{pH}$, and base excess decreased significantly throughout the whole study for the entire group.

\section{Discussion}

Pryor $e t$ al used self treatment in the form of forced expiratory technique, 'huffing', combined with postural drainage, percussion, vibration, and chest compression - that is, similar to our method-and found it as effective as the same treatment when carried out by a physiotherapist. ${ }^{9}$ Our results are similar, including that some of the parents were not able to abstain completely from helping their children.

It has also been reported that directed vigorous cough might be as effective as chest physiotherapy treatment in removing mucus from the lungs. ${ }^{10} 11$ Another method for self treatment is 'autogenic drainage', which also have been reported to give good results. ${ }^{12}$ Equipment for mechanical percussion, such as the Salford Percussor, has not been found to be more effective than manual percussion in combination with postural drainage. ${ }^{13}$

Studies have also been carried out showing that patients with cystic fibrosis can participate in organised, guided physical activity, including marathon running. ${ }^{14} 15$ Zach et al reported in a short term study that regular physical exercise and sports could be a substitute for the inhalation and physiotherapy routine. ${ }^{16}$ Due to the high intensity level of the programme it was impossible to fit it in to the daily life of the children, and after finishing the programme most of the variables returned to pretraining levels. The explanation of our better results compared with those in another recent study ${ }^{17}$ could be due to the individually formed exercise programmes we used. Holzer et al used standardised programmes. ${ }^{17}$ The standardised exercise of rope skipping we advised was not completed in any case.

In a long term study by Orenstein et al most of the patients with cystic fibrosis could exercise safely, and physical activity was as beneficial as the conventional chest physiotherapy treatment with postural drainage. ${ }^{18}$ Our results support previous studies and show that most patients with cystic fibrosis can exercise safely. ${ }^{14}{ }^{19}{ }^{20}$ No patient deteriorated and most patients tended to show an improvement in the results of their pulmonary tests, although significant changes were only noticed in oxygen pressure and some other blood gas analyses, indicating more efficient muscle work. The limitations of significant changes might partly be due to the small series of patients. The physical activity seems to be the most important part of the programme as most changes were noticed during phase A.

In other studies of physical activity the participants have been carefully guided, mostly in small groups. This study shows that patients with cystic fibrosis, after instructions on an outpatient basis, can use the self treatment method in combination with physical activity during their daily life and that this type of combined treatment gives as good a result as conventional physiotherapy treatment. For each individual patient the benefit of becoming independent must make self treatment preferable to conventional physiotherapy treatment.

We thank Mrs Irèn Ládànyi for technical help and Mrs Marianne Westrell for typing the manuscript. This work was funded by grants from Stockholm's Läns Landsting, the Swedish National Association against Heart and Chest Diseases, and the Royal Wedding Foundation.

\section{References}

1 Hodson ME, Norman AP, Batten JC. Cystic fibrosis. London: Ballière Tindall, 1983.

2 Gaskell DV, Webber BA. The Brompton Hospital guide to chest physiotherapy. 4th ed. London: Blackwell Scientific Publications, 1980:13-30.

3 Thompson B. Asthma and your child. 5th ed. New Zealand: Pegasus Press, 1978;18-9.

4 Shwachmann H, Kulczycki L. Long-term study of one hundred and five patients with cystic fibrosis. Am J Dis Child 1958;96: 6-15.

5 Quanjer PH. Standardized lung function testing. Clin Resp Physiol, 1983;5:suppl 5.

6 Engström I, Karlberg P, Swarts CL. Relationships between mechanical properties of the lungs, lung volumes and ventilatory capacity in healthy children 7-15 years of age. Acta Paediatr Scand 1962;51:68-80.

${ }^{7}$ Fridriksson HV, Malmberg P, Hedenström H, Hillerdal G. Reference values for respiratory function tests in males: prediction formulas with tobacco smoking parameters. Clin Physiol 1981;1:349-64.

$\checkmark$ Hedenström H, Malmberg P, Hillerdal G. Reference values for respiratory function tests in females; prediction formulas with tobacco smoking parameters. Clin Resp Physiol. (In press.)

' Pryor JA, Webber BA, Hodson ME, Batten JC. Evaluation of the forced expiration technique as an adjunct to postural drainage in treatment of cystic fibrosis. Br Med J 1979;ii:417-8.

16 Rossman CM, Waldes R, Sampson D, Newhouse MT. Effect of 
chest physiotherapy on the removal of mucus in patients with cystic fibrosis. Am Rev Respir Dis 1982;126:131-5.

"De Boeck C, Zinman R. A comparison of the acute effects on pulmonary function in patients with cystic fibrosis. Am Rev Respir Dis 1984;129:182-4.

12 Chevallier J. Autogenic drainage. In: Lawson D, ed. Cystic fibrosis horizons. London: John Wiley and Sons, 1984:235.

13 Pryor JA, Parker RA, Webber BA. A comparison of mechanical and manual percussion as adjunct to postural drainage in the treatment of cystic fibrosis in adolescents and adults. Physiotherapy 1981;67:140-1.

${ }^{14}$ Hjeltnes N, Stanghelle JK, Skyberg D. Pulmonary function and oxygen uptake during exercise in 16 year old boys with cystic fibrosis. Acta Paediatr Scand 1984;73:548-53.

is Stanghelle JK, Skyberg D. The successful completion of the Oslo marathon by a patient with cystic fibrosis. Acta Paediatr Scand 1983;72:935-8.
16 Zach M, Oberwaldner B, Häusler F. Cystic fibrosis: physiological exercise versus chest physiotherapy. Arch Dis Child 1982;57:587-9.

17 Holzer FJ, Schnall R, Landau LI. The effect of a home exercise programme in children with cystic fibrosis and asthma. Aust Paediatr J 1984;20:297-302.

18 Orenstein DM, Henke KG, Cerny FJ. Exercise and cystic fibrosis. Phys Sports Med 1983;11:57-63.

19 Cropp GJ, Pullano PT, Cerny FJ. Nathanson IT. Exercise tolerance and cardiorespiratory adjustments at peak work capacity in cystic fibrosis. Am Rev Respir Dis 1982;126:211-6.

${ }^{20}$ Godfrey S, Mearns MM. Pulmonary function and response to exercise in cystic fibrosis. Arch Dis Child 1981;46:144-51.

Correspondence to Dr B Strandvik, Department of Paediatrics, Huddinge University Hospital, S-141 86 Huddinge, Sweden.

Received 20 December 1985 